\title{
Uri Caine’s Mahler: Jazz, Tradition, and Identity
}

\author{
BJÖRN HEILE
}

\begin{abstract}
Although Uri Caine first made his mark as a relatively straight-ahead jazz pianist - 'roots' to which he returns regularly - he has, arguably, become most famous with his often controversial versions of works from the 'classical music' canon. These recompositions, which often involve a host of other styles from Latin to dub, are usually regarded as examples of postmodern eclecticism. While this view is certainly valid, it needs to be complemented by more detailed analysis of both Caine's artistic methods and their aesthetic and ideological implications. Among his work on classical composers, Caine's engagement with Gustav Mahler is the most sustained. The result of this engagement is not an exercise in 'crossover' or 'jazzed-up' Mahler, but a radical reinterpretation of Mahler's music that situates it as a Jewish voice within the cultural cross-currents of fin-de-siècle Central Europe. Through this reference to Mahler, Caine constructs a Jewish tradition within jazz that complements but does not compete with jazz's overwhelmingly African-American heritage. What emerges is a pluralistic subjectivity in which different cultural identities and traditions are negotiated in an equal and open dialogue.
\end{abstract}

\section{Style and Identity}

The title of this article, 'Uri Caine's Mahler', is ambiguous. Its wording parallels that of 'Bruno Walter's Mahler' and 'Leonard Bernstein's Mahler', thus alluding to noteworthy performances of Mahler's work. But we are as likely to speak of 'Luciano Berio's Mahler' and, for that matter, 'Arnold Schoenberg's Mahler', denoting, respectively, a compositional use (in the third movement of Berio's Sinfonia) and an arrangement (Schoenberg's orchestrations of Mahler's Lieder eines fahrenden Gesellen for the Verein für musikalische Privataufführungen). As the possessives signal, all make different claims for Mahler's legacy.

This ambiguity, however, is intentional, since it is unclear whether Uri Caine's engagements with Mahler can be described as performances of his work, as arrangements, or as recompositions. They seem to switch irreverently between these categories or to combine them in unpredictable ways. It could be argued that, for a jazz pianist such as Caine, the categorical distinctions operating in classical music between performance, arrangement, and recomposition do not apply. Yet, rather than simplifying the issue, this only highlights the clash between the respective traditions of classical music and jazz and their implicit ideologies. Reading Caine's work from the perspective of the reception history of Mahler produces a very different result from viewing it in the context of jazz. The complication arises from

This article is an edited version of a paper delivered at the University of Surrey and, in revised and abridged form, at the Leeds International Jazz Conference 'Jazz, Politics and the Popular' in 2006. I wish to thank the following for their comments on these or other occasions: Peter Elsdon, Stephen Goss, Julian Johnson, and Alan Stanbridge, as well as two anonymous reviewers for twentieth-century music. I am particularly grateful to Stefan Winter of Winter \& Winter and Uri Caine for their helpful replies to my queries, and to Naomi Tadmor for her help with Hebrew. 
Caine's skirting of the borderline not only between the competing claims of jazz and classical music, but also between different conceptions of the nature of authorship and text.

Moreover, Mahler's music, located as it is between romanticism and modernism, between urban Christian Western Europe and its rural East European or Jewish other, and between a Central European legacy (embodied by Walter) and an American claim for inheritance (represented by Bernstein), is contested territory - much more so than the classical music that has long been influential among jazz artists, such as Bach's. Hence my distinguishing between different textual and stylistic categories - that is, between performance, arrangement, and composition, as well as between jazz and classical music - should not be seen as a self-legitimizing academic exercise or a quest for the most convenient label, but as an ontological approach, an enquiry into the nature of Caine's music. Rather than presupposing their often-heralded demise, my starting point is that categories, both textual and stylistic, matter, at least in so far as they are applied intelligently and not as marketing slogans. What I mean is that, in trying to make sense of music, we relate it to other forms of music. Music's nature is never exclusively intrinsic but always also relational. Any music carries with it claims for various traditions and legacies; it foregrounds certain influences and, just as importantly, obscures others. Through the very act of enunciation, music situates itself.

This is why, in a nutshell, Caine's evasion of categorical boundaries is so disruptive, not because he synthesizes different traditions - that is hardly novel in an era of stylistic pluralism - but because of the way he negotiates their claims for identity. His music refuses easy identification, including that of being a 'mixture of things', and the inability to recognize something, to pin it down by relating it to known categories, is a disquieting experience. As will be seen, although Caine's approach to Mahler is informed by jazz, jazz is not necessarily predominant stylistically. Whatever else Caine's music may be, 'jazzed-up' Mahler it is not.

In the following discussion I aim to elucidate the different traditions that Caine references, and the claims for Mahler's legacy that are constructed by these practices.

\section{Genesis and Biography}

Uri Caine's interest in Mahler has so far led to two studio-produced CDs, Urlicht/Primal Light (1997) and Dark Flame (2003), as well as a double CD with live versions of the tracks from Primal Light performed during the Gustav Mahler Festival 1998 in Toblach, the location of Mahler's final composing hut (Gustav Mahler at Toblach: I Went Out This Morning over the Countryside, 1999). ${ }^{1}$ While Urlicht contains both fragments from the symphonies and material from the song cycles, Dark Flame is devoted entirely to lieder. A version of Symphony No. 9 was planned, which would represent a significant departure from Caine's usual practice of dealing with relatively short sections of music, but so far this has apparently not been realized. ${ }^{2}$ In 2006 Caine's own website announced a live performance of

1 For details of these and other Uri Caine recordings mentioned in the text see Discography, Filmography below.

2 See Schaal, "“Wie können Sie das Mahler antun?”', 64. 
a 'Remix of Mahler's 6th', and in a personal communication he has mentioned a performance of passages from Symphony No. $3 .^{3}$

Caine reports that he used to study Mahler with his composition teacher George Rochberg, and later on with George Crumb, and this exposure evidently left its traces. ${ }^{4}$ Nevertheless, the Mahler projects were originally the brainchild of Caine's producer Stefan Winter, who was working with his brother Franz Winter on what they call 'a cinematic biography' of Mahler. Having noticed the quotation of the opening motto of Mahler's Symphony No. 1 (A-E-F-C-D-B b ) in the first track of Caine's Toys ('Time Will Tell') - no mean feat given that the funk backing makes the tune all but unrecognizable despite its being quoted literally - Winter asked Caine to produce music for the film. According to the liner notes to Primal Light, the film, in its original, silent version, was first presented with live accompaniment by the Uri Caine Ensemble in late November 1995 at Manhattan's Knitting Factory (a significant location, as will be seen). ${ }^{5}$ The revised DVD version of the film, now with spoken commentary and entitled Ich bin der Welt abhanden gekommen/Detaching from the World, did not appear until 2005. It features tracks from both Urlicht and Dark Flame as well as from Caine's Wagner adaptations on Wagner e Venezia (1997); Caine is also employed as speaker on the English version. ${ }^{6}$ This is not the place for a detailed discussion of the use of the music in the film; suffice it to say that the selection of material, as well as some aspects of its adaptation, is often related to the scene in the film that the music accompanies. For instance, the first track on Urlicht - the funeral march from the first movement of Symphony No. 5 - is used to accompany the opening shot of Mahler's tombstone; 'Nun will die Sonn' so hell aufgeh'n' from Kindertotenlieder accompanies footage from the Jewish cemetery in Iglau where Mahler grew up, with electronic insect and bird sounds on the soundtrack illustrating the pastoral scenery; and the Prelude from Tristan und Isolde from Wagner e Venezia is played when Mahler's success as a conductor of that work is mentioned in the film (that 'Der Abschied' from Das Lied von der Erde predominates in the closing scenes of the film dealing with Mahler's death is almost predictable). But not all the music is used in obviously illustrative fashion; neither are Caine's interest in Mahler and his approach to the music solely conditioned by the film: after all, only seven of the eleven tracks of Urlicht and just two of those from Dark Flame are used in the film (since it did not appear until 2003, Dark Flame was not directly connected with the original film at all; it was used only for the DVD version). Clearly, Caine's enthusiasm wasn't exhausted after the original project had been concluded. Following Urlicht, he also made adaptations of the music of Wagner, Bach, Schumann, Beethoven, and, most recently, Mozart. But his interest in Mahler is most sustained, and, to my ears, results in the most personal music: it sounds as if he has found a kindred spirit in Mahler (Caine's Goldberg Variations (2000), for instance, are brilliantly inventive, yet they seem more detached by comparison).

Caine, <http://www.uricaine.com/news.html> (accessed 25 May 2006); personal e-mail dated 6 June 2006.

See Schirmer, 'Meet Uri Caine'. Caine has confirmed this in a personal e-mail dated 6 June 2006.

Winter, Liner notes to Gustav Mahler/Uri Caine, Primal Light, [4].

6 I should like to thank Stefan Winter for answering my questions regarding the genesis of the film and its relation to the CDs (personal e-mails, 24-6 May 2006). Winter also confirmed that the original version of the film shown at the

Knitting Factory did not contain a spoken commentary. 
Caine's roots in jazz and classical concert music can be traced back to the beginning of his development in his native Philadelphia, and his pedigree is impeccable in both. ${ }^{7}$ Originally learning classical piano - more the rule than the exception among today's jazz pianists - he quickly became interested in jazz. One of his first jazz teachers, the French pianist Bernard Peiffer, emphasized the importance of classical music, specifically with regard to the development of a solid technique. While studying composition with George Rochberg, Caine also frequented the local jazz clubs. As a student at the University of Pennsylvania, where his teachers included George Crumb, ${ }^{8}$ he became a regular performer in these clubs, playing with notable artists such as 'Philly' Joe Jones ('Philly' standing for Philadelphia), Mickey Roker, Bobby Durham, and Bootsie Barnes. As is still the norm among American jazz musicians, he went to New York, and the week-long engagement of his Trio in May 2003 at the Village Vanguard, arguably the most prestigious jazz club in the world, marked his acceptance as one of the leading jazzmen. Although Bill Shoemaker, in the influential Down Beat magazine, is unenthusiastic about the resulting CD, Live at the Village Vanguard (2004), on account of the surprisingly traditional trio-playing, he concedes Caine's 'staggering virtuosity', remarking that his 'brilliance is best expressed on a monumental scale' (his otherwise lukewarm evaluation does not prevent him from giving the album four stars). ${ }^{9}$ But Caine's New York roots lie at the downtown Knitting Factory, a venue more renowned for avant-gardist experimentation, not least on account of the connection with its 'doyen', the altoist and composer John Zorn.

Jazz credentials such as these distinguish Caine from the conventional image of the 'crossover star'. Indeed, in his extremely diverse and eclectic output, relatively straight-ahead jazz appears as the point of departure and constant reference. Not only did his first two CDs, Sphere Music (1993) and Toys (1995), pay homage to the jazz greats Thelonious Monk and Herbie Hancock, respectively, but he has also returned regularly to these roots, as on Live at the Village Vanguard, the funk-inspired Shelf-Life (2005), his solo album Solitaire (2001), and his arguably most straight-ahead album Blue Wail (1998). These activities are complemented by his work as a sideman to such luminaries as trumpeter/composer Dave Douglas and clarinettist/composer Don Byron. His reworkings of classical pieces constitute the most significant second strand. But he has also engaged with Jewish music in Zohar: Keter (1999), samba and related styles in Rio (2001), and Tin Pan Alley in The Sidewalks of New York

7 The biographical sketch provided here is based on Gilbert, 'Caine, Uri'. There are numerous Internet resources with basic biographical information on Caine, including his own website <http://www.uricaine.com> (accessed 19 November 2007). Arguably, the most comprehensive and informative source is Schirmer, 'Meet Uri Caine'. There are no significant deviations between different sources (which are presumably all based on Caine's own testimony); Caine has confirmed certain aspects in a personal e-mail dated 6 June 2006.

8 It is perhaps worth noting that Caine studied with two composers who are very notable exponents of eclecticism, albeit in different ways; the position they represent within classical music has certain affinities with Caine's within jazz. Nevertheless, while Caine is extremely grateful to his teachers, he sees their influence more in the rigorous technical and historical grounding they provided than in their personal aesthetic stance (not to mention that he mostly played four-hand piano with Crumb): see Schirmer, 'Meet Uri Caine'. In a personal e-mail dated 6 June 2006 Caine confirms his indebtedness to both composers, but stresses that this is not connected with their aesthetic positions.

9 See Shoemaker, review of Uri Caine, Live at the Village Vanguard; cf. Andrew Lindemann Malone's more positive review of the same CD in JazzTimes. 
(1999). The last of these is particularly relevant as regards Caine's engagement with his source materials. While there is little novelty about jazz musicians exploring the Tin Pan Alley tradition of popular songs - the origin of many of the so-called 'standards' - the almost scholarly historical approach Caine takes is noteworthy. In many ways the album sounds more like an exercise in imaginary acoustic archaeology than a straightforward CD; needless to say, he also explores parts of the Tin Pan Alley repertoire that are not canonized by The Real Book. ${ }^{10}$ As David Ake has demonstrated, playing standards can reference very different traditions, or aspects within the same tradition; he points out how Wynton Marsalis constantly refers to great African-American precursors who have shaped particular tunes, thereby all but obscuring the original composers. ${ }^{11}$ Caine, on the other hand, wishes to connect directly with the origin of the tunes whose creators were from diverse backgrounds. Indeed, he seems to make a point of this diversity by including Irish ditties, Yiddish songs, and pieces by Eubie Blake and W. C. Handy - all in appropriate (if not necessarily authentic) performance practice - while the title track is by the Russian-Jewish immigrant Irving Berlin.

Although Caine's work in the classical sphere makes the most headlines - Urlicht, for instance, won a Special Prize at the 1997 international Toblacher Komponierhäuschen awards $^{12}$ - he remains a jazz pianist. Indeed, what is significant is how Caine seems to inhabit different identities simultaneously, rather than opting for a synthetic new identity or rendering eclecticism as a category in its own right. It is one of the goals of this article to demonstrate that, rather than representing a marketing exercise in crossover or shallow postmodernist eclecticism, Caine's recompositions of Mahler are a profound engagement with the relationship between history and subjectivity.

\section{Traditions}

Jazz adaptations of classical music are hardly a new phenomenon. On the contrary, throughout the history of jazz there have been various intersections with classical music. Since this aspect has been covered elsewhere, only the broad outlines need to be recounted here. ${ }^{13}$ In what is a remarkable precursor to Caine's practice, Jelly Roll Morton, the self-styled inventor of jazz, considered jazz a style of playing appropriate to any kind of music, rather than a repertoire, and he used the term as a verb, not a noun. Accordingly, he had classical pieces in his repertoire, as had others at the time, such as Eubie Blake. From then on, classical compositions continued to pop up in unexpected places, such as the

10 The Real Book is a so-called 'fake book' that contains 'lead sheets', that is, the tunes and 'changes' (harmonies) of jazz standards. The original editions were illegal, owing to copyright infringements, but there is now a legal edition, published as The Real Book, Vol. 1, 6th edn.

11 Ake, Jazz Cultures, 146-64.

12 See <http://www.gustav-mahler.it/en/en_schallplattenpreis_gustav_mahler_toblach_dobbiaco.asp?MAID=152\&APP $=8 \& \mathrm{LG}=3 \& \mathrm{NKey}=$ recordprize $>$ (accessed 19 November 2007). The award was for what the jury (in a somewhat ill-informed expression) regarded as Caine's 'experimental transcriptions of Mahler's themes'.

13 See, for instance, Joyner, 'Analyzing Third Stream', and Cooke, 'Jazz among the Classics'. The examples mentioned here are mostly mine, though. 
Oscar Peterson Trio's rendition of Dvořák's Humoresque (Peterson had studied classical piano at the Montreal Conservatory), Charlie Mingus's combining of Rachmaninov's Prelude in C\# minor with Kern-Hammerstein's 'All the Things You Are' to form 'All the Things You C\#', Duke Ellington's arrangements of Grieg and Tchaikovsky, and, more recently, Bob Belden's arrangements of pieces by Bach, Tchaikovsky, and Rachmaninov for the Classical Jazz Quartet. ${ }^{14}$ These approaches are mostly regarded nowadays as the slightly disreputable underside of the great jazz tradition, which can be belittled as variety acts, attempts to partake of the prestige of classical music, lovable eccentricity, or simple tackiness. But such judgements are not beyond critique, and Mervyn Cooke, for one, seems intent on rescuing the reputation of Ellington's Tchaikovsky arrangements. ${ }^{15}$ At least it is safe to say that there is a more or less continuous history of 'jazzed-up' versions of classical music.

In this context one should also mention the many jazz musicians who have been influenced by contemporary classical music on one level or another - Charlie Parker, Miles Davis, Bill Evans, and Cecil Taylor among them. But there have also been more ambitious attempts to fuse jazz and classical music, the most influential of which was Gunther Schuller's concept of 'third stream' music. Rather than jazzed-up classical music, or symphonic jazz, or jazz with strings, this was an attempt to 'fuse the improvisational spontaneity and rhythmic vitality of jazz with the compositional procedures and techniques acquired by Western music during seven hundred years of musical development'. ${ }^{16}$ Schuller saw this concept realized by Gil Evans and Dave Brubeck, and by John Lewis in his work with the Modern Jazz Quartet, and he also endeavoured to fulfil it in his own compositions. Today, there is something of a consensus that third stream was a failure, and many reasons have been advanced to account for this. ${ }^{17}$ Nevertheless, Schuller's perceptiveness in spotting developments that were then current cannot be denied, but one reason why the concept failed to catch on is precisely that what had once been trumpeted in the style of a manifesto had quietly become reality. A lot of contemporary jazz consists of sophisticated combinations of composition and improvisation in which it is often unclear to listeners what has been prearranged and what is improvised.

Given that 'third stream' referred to a concept for the creation of a new style of music rather than the playing of jazz versions of classical pieces, its mention in the present context may seem slightly irrelevant. However, Caine's music has been described as 'modern third stream', 18 a claim that is not wholly nonsensical, since his work has to be viewed in the context of the history of interactions between jazz and classical music, in which third stream plays a major part. In recent years such interactions have become increasingly common and prominent. As Darius Brubeck has pointed out, performers as opposed to one another as

14 Kenny Barron (piano), Ron Carter (bass), Stefon Harrison (vibraphone, marimba), Lewis Nash (drums).

15 See Cooke, 'Jazz among the Classics'.

16 See Schuller, 'Third Stream', 410, and 'Third Stream Revisited', 413-14.

17 See Joyner, 'Analyzing Third Stream', and Wilson, 'Unerledigte Fragen'.

18 See Blumenthal, 'Worldly Music' and 'Third Stream from the Source', and Mehldau, 'Brahms, Interpretation and Improvisation' (articles that comprise the section 'New World Symphonies: a Survey of Modern Third Stream' in JazzTimes, February 2001). 
Wynton Marsalis and Keith Jarrett share at least one quality: both have produced highly regarded interpretations of classical work. ${ }^{19}$ Chick Corea and Bobby McFerrin have similarly 'strayed' into classical territory, the first playing jazzy improvised cadenzas in otherwise straight performances of Mozart piano concertos. Friedrich Gulda took the opposite path and jeopardized his career as a concert pianist by moonlighting as a jazz player. Like Chick Corea, Gulda also explored various combinations of the two musics, not least on the notable occasions when he and Corea appeared together.

It is not difficult to find reasons for these developments: jazz's prestige is now more or less equal to that of classical music, so performers are less likely to be accused of seeking a higher status through illegitimate means, or, conversely, of 'betraying their art' and selling out if they stray from what is considered to be their terrain. Furthermore, today's musicians tend to have grown up under the influence of many musical cultures: jazz musicians often train at conservatoires, and classical musicians listen to jazz, popular, and world music in their free time. No wonder, then, that an exclusive identification with one type of music seems alien to many. Finally, and related to the points already mentioned, postmodern pluralism has led to a questioning of stylistic boundaries, even though one should not underestimate the continuing force exerted by different traditions and lineages, whether through training and habituation or by offering a sense of identity.

There have also been a host of more adventurous approaches towards the classical tradition by jazz artists: for example, Jan Garbarek's collaboration with the Hilliard Ensemble for their album Officium; Joachim Kühn's Mozart appropriations on Piano Works I: Allegro Vivace; the Viennese drummer/composer Christian Mühlbacher's Mozart Revisited with his ensemble Nouvelle Cuisine; Louis Sclavis's Les Violences de Rameau; 20 and the Goldberg Variations by Sebastian Hauss and Oberkarl (a successor to Caine's The Goldberg Variations). Uri Caine's music, therefore, does not fall into a vacuum. But there is an important difference between Caine and the artists just mentioned: unlike them, he is American and clearly part of an American jazz tradition. European jazz musicians have often drawn from 'native' traditions, just as Americans have drawn from theirs. In addition to folk music (exploited by a range of artists from Django Reinhardt and Stéphane Grappelli to Jan Garbarek and Louis Sclavis), classical music was one of the chief sources of inspiration: in this regard, Jacques Loussier's Play Bach Trio was pioneering (whatever else one may wish to say about their work).

American jazz musicians, on the other hand, seem to have become less keen on appropriating the classical repertoire in their music, other than performing it in more or less traditional fashion (the Classical Jazz Quartet may be an exception in this regard, but their music is so tame and inoffensive that it cannot be compared with the rather more creative appropriations undertaken by Caine and some of the other musicians mentioned here). However, some have explored the American classical tradition. They include Bill Frisell, who, on his album Have a Little Faith, ${ }^{21}$ seems to attempt nothing less than to examine a

19 Brubeck, '1959: the Beginning of Beyond', 195.

20 CDs, respectively: ECM New Series 1525 (1999); Act 9750-2 (2005); Quinton Q0502 (2005); ECM 1588 (1996).

21 CD, Elektra/Nonesuch 9 79301-2 (1993). 
cross-section of musical Americana, from traditional songs through a march by John Philip Sousa, Aaron Copland's Billy the Kid, and pieces by Charles Ives, to a tune by Sonny Rollins and songs by Bob Dylan and Madonna. ${ }^{22}$

In the US context, therefore, Caine's approach is far from common. But then, he is Jewish, and his interest in Mahler seems to have less to do with Mahler's status as a classical composer than with his Jewish heritage - an important contrast with the often generic conception of 'classical music' among jazz artists. As he describes it himself: 'I used to listen to Mahler's music in concerts by the Philadelphia Orchestra. And sometimes I thought: If you played this passage like that at a Jewish wedding, they would throw you out!'23 Rather than the symphonic discourse, Caine refers here specifically to the folk music representations contained within Mahler's music, which he seems to regard - somewhat contentiously, as will be seen - as Jewish.

This quest for a Jewish heritage links Caine to the Knitting Factory, the home of the Jewish Alternative Movement, as well as to its spiritus rector John Zorn, the main proponent of the idea of 'Radical Jewish Culture'. ${ }^{24}$ Indeed many, if not all, of Caine's collaborators on the Mahler albums are associated with the Knitting Factory and are often veterans of the various outfits of John Zorn or Zorn's erstwhile sideman Bill Frisell, although Caine stresses that he met many of them in the ensemble of his clarinettist Don Byron. ${ }^{25}$ Caine's collaborators all contribute their personal style and sound: when it comes to the creation of a specifically Jewish, often klezmer-influenced, idiom (to which I shall return below), Byron and the violinist Mark Feldman, not to mention the cantor, the Moroccan-born Aaron Bensoussan, arguably play more important roles than Caine (in so far as there is no specific performance practice for piano). ${ }^{26}$ Indeed, Caine employs the individual personalities of his co-musicians in a manner reminiscent of Duke Ellington (so much so that if, in this article, I speak of 'Uri Caine', this is often short for 'Uri Caine and his ensemble', although the conceptions and arrangements are his).

Needless to say, Caine's Zohar: Keter has to be seen in the context of the Jewish jazz music scene centred on the Knitting Factory, and a similar argument can be made for parts of The Sidewalks of New York. Moreover, he also features on CDs produced by Zorn's label Tzadik. More recently, Caine has recorded Zorn's Masada Songbook II under the title Moloch: Book of Angels Volume 6 (2006). In his public statements Caine does not share Zorn's missionary zeal, and in a personal e-mail he was likewise keen to stress that he 'would not want to be limited to this [Jewish music] because [he] love[s] so much other music!'. He also distances himself from 'narrow racial stereotyping'. Nevertheless, he clearly identifies with his parents' deep commitment to a (mostly secular) Jewish and

22 Cf. Ake, Jazz Cultures, 164-76.

23 See Schaal, "'Wie können Sie das Mahler antun?”', 63.

24 See Kennedy, 'Zorn, John'; Wilson, 'Zorn, John'; and Nicholson, 'Fusions and Crossovers'.

25 Personal e-mail dated 6 June 2006.

26 As regards Bensoussan, Caine cleverly 'justifies' the employment of a cantor on the basis of Mahler's admiration for a cantor (see Schaal, "'Wie können Sie das Mahler antun?”', 63). Don Byron is an interesting case of an AfricanAmerican clarinettist who became fascinated by klezmer while at university in Boston, away from the klezmer revival centred on Manhattan (see Gilbert, 'Byron, Don'). 
specifically Hebrew culture (and radical politics), and names Israeli music as among his first musical influences. ${ }^{27}$

\section{The Recordings}

In the following discussion I shall analyse the tracks on Urlicht and Dark Flame with regard to certain aspects that centre on the music's relationship to Mahler's originals. I have not included Gustav Mahler in Toblach since it consists of the same arrangements as Urlicht, only slightly modified to accommodate the reduced line-up (although in the case of 'The Farewell'/'Der Abschied' the revisions are a little more substantial). The main difference between Urlicht and Gustav Mahler in Toblach is that on the latter the solos tend to be more extended, to my mind often bordering on self-indulgence (although they may have been exciting in the live context).

\section{Arrangement}

Perhaps the most striking aspect of Caine's work is how literal most of it is. He has arranged the material much as a classical composer would: all of the tracks can easily be followed in the scores of Mahler's originals, and doing so increases one's appreciation of Caine's art. The stylistic variety that reviewers tend to find in his music is due to performance practice and improvised additions to the original material (which will be discussed in more detail below). In arranging the original material, however, Caine tends to abridge and simplify the form to a significant degree, preferring simple ternary and strophic forms to Mahler's often complex formal outlines. Ternary forms in particular are almost archetypal in both classical music and jazz (in the conventional arrangement of opening tune-solos-tune). Furthermore, he prefers to stay in the same key or return to the original key at the end of a piece, which Mahler does not always do.

The rendition of the first movement funeral march from Mahler's Symphony No. 5, which forms the programmatic first track of Urlicht, is conspicuous in its fidelity to the original: practically all the music played is by Mahler. However, Caine breaks off before the trio in $\mathrm{B} b$ minor (b. 155, fig. 7), returning instead to the opening before closing with a postlude of indistinct speech and electronic noise. ${ }^{28} \mathrm{~A}$ similar approach is taken in the third movement of Symphony No. 1, the mock funeral march on a variant of the 'Frère Jacques' canon in D minor (also on Urlicht). After the first canon and the first trio have been performed practically note for note, the performers break into an extended klezmer episode at the point at which, in the original, there is a brief restatement of the original canon (fig. 9). More significantly, Caine cuts all further sections in the Mahler, such as the second trio (the Volksweise in $\mathrm{G}$ major) and the return of the canon in a jarring $\mathrm{E} b$ minor, proceeding instead

27 Personal e-mail dated 6 June 2006; see also Schirmer, 'Meet Uri Caine'.

28 Barbara R. Barry speaks of a 'double exposition structure of the movement', according to which what I described as the trio would presumably be the development section; see Barry, 'The Hidden Program in Mahler's Fifth Symphony', 55. In any case, however one may analyse the form, what is significant is that Caine breaks off at the first major formal juncture and returns to the opening in its original key. 
to a variation of the opening canon in its original $\mathrm{D}$ minor, thus once again producing a ternary form (if one does not count the klezmer episode as a formal section: in general, it makes more sense to treat added material as separate from the material directly derived from Mahler). Another related instance is provided by the version of the fourth movement of Symphony No. 2, 'Urlicht' (on the CD of the same title), where Caine arranges just the opening chorale (bb. 1-35). There is only one example of a movement performed in its entirety: the (relatively short) Adagietto fourth movement from Symphony No. 5 (Urlicht).

In one instance Caine has combined material from two different works: 'I Went Out This Morning over the Countryside' ('Ging heut' morgen über's Feld') from Lieder eines fahrenden Gesellen, and the first movement of Symphony No. 2, Allegro maestoso (not the second movement, Andante moderato, as stated on the CD). ${ }^{29}$ But here too Caine suggests a ternary form: the lied tune is given to a jazz piano trio, after which the (plucked) bass, accompanied by funky drumming, introduces the opening of Symphony No. 2 (which, in the original, is scored for cellos and double basses); this is followed by a return of the piano trio. This ternary framework is further elaborated by a piano solo after the opening tune and a bass solo in between statements of the symphony material, but these insertions do not alter the overall form significantly. Although Caine does not restate the lied tune at the end, except for some melodic fragments, combined with fragments from the material from Symphony No. 2, the instrumentation is enough to create the feeling of 'homecoming' typical of ternary forms.

The same formal principles are also applied to the songs, although, owing to their usually simpler strophic forms, they tend to present fewer difficulties. As Caine himself has pointed out, ${ }^{30}$ his approach to classical compositions is not so different from the way in which Charlie Parker would have adapted an Irving Berlin tune. This may explain why, with Dark Flame, he produced another CD entirely with songs: the adaptations tend to be simpler with respect to form - which is to say that usually the complete song, or at least one or several strophes, is arranged - but it seems that this gave Caine more freedom to experiment with other aspects such as style and instrumentation. Needless to say, though, there are a couple of complex songs that require more active arrangement; in fact, some of the most skilful adaptations on Urlicht concern song material. It is in keeping with Caine's usual practice, observed above with respect to symphonic material, that in 'The Drummer Boy' ('Der Tambourg'sell') from Des Knaben Wunderhorn he ignores the modulation from D minor to $\mathrm{C}$ minor, in which the original closes. By contrast, his adaptation of 'The Farewell' ('Der Abschied') is a tour de force. With its overall length of about thirty minutes, the original is clearly too unwieldy (the dense orchestration of some passages would also have created difficulties); but, presumably on account of its expressive force, Caine was clearly not prepared to use only a fragment of the piece. Instead, he chose 'representative' sections that, in succession, capture some of the formal architecture as well as the emotional trajectory of

29 The live version of 'Der Abschied', which concludes Gustav Mahler in Toblach, also introduces fragments from pieces heard earlier in instrumental solos.

30 In an interview with Michelle Merce, 'A Man of Ideas Searches for Musical Metaphors', New York Times, 17 September 2000; quoted from Cotro, 'La Résurgence du passé dans le jazz contemporain’, 452. 
the original. Specifically, as can be seen in Figure 1, he selected the opening up to b. 39, where Mahler introduces a contrasting section, replacing the recitative in bb. 19-26 with a much longer recitation for the cantor. He then jumps to b. 323 (!), where the funeral-march motive in parallel thirds from the first section recurs with a different counterpoint, and continues up to the second recitative in b. 374 . The latter is again given over to Bensoussan, after which the musicians rejoin the Mahler at b. 459, the coda, which is played in its entirety, with the trumpet carrying the vocal line. Figure 1 suggests another rationale for the selection of material: as usual, Caine has restricted himself to sections in $\mathrm{C}$ major or minor, whereas the original modulates widely and establishes a secondary tonal centre of A minor. One of the effects of this emphasis on the funeral-march element is that the piece's association with death becomes even more foregrounded (see below). Again, most of the material is by Mahler: apart from some noise passages to link the different sections of the Mahler, only the cantor's recitation is apparently semi-improvised, but that too sticks to the $\mathrm{C}$ minor-F minor $6 / 4$ alternation of the original (with added notes).

Yet Caine does not always simplify complex forms. One example of a relatively intricate formal structure that is reproduced almost in its entirety, with further segments added, is 'The Drunkard in Spring' ('Der Trunkene im Frühling') from Das Lied von der Erde (Urlicht). As Figure 2 illustrates, Mahler's song consists of seven strophes in relatively regular seven-bar phrases, arranged in an overarching ternary form. ${ }^{31}$ Caine arranges the complete song (although after two strophes he consistently cuts the two introductory bars of each strophe), his extraordinarily varied instrumentation heightening the already marked contrast between the 'a' and 'b' sections of each strophe (representing, respectively, the drunkard's awareness of the renewal of life around him and his nihilistic drive to intoxicate himself). ${ }^{32}$ But in this already complex scheme are inserted solo sections for all melody instruments in diverse styles and tempos. Caine's clear analysis of the original is evidenced by his placing of all solos at the same formal juncture, namely at the beginning of a new strophe (in the first two instances after the introductory two bars; in all others, replacing these); this demonstrates, if proof were needed, that what interests Caine most is the relationship between improvisation and composed structure. ${ }^{33}$

Like the formal arrangements, the instrumentations are very varied, ranging from an intimate duet between the clarinet (playing the vocal part) and piano (with electronics) in 'Now Will the Sun Rise as Brightly' ('Nun will die Sonn' so hell aufgeh'n!') from Kindertotenlieder (Urlicht), to the full line-up, particularly in the symphonic movements. Whenever he has several instruments at his disposal, Caine tends to change instrumental roles frequently, instead of assigning instruments to parts in a fixed manner. Although he shows a preference for using the same or similar instruments to the original when available, he is not averse to more adventurous effects, often reinterpreting the structure. For instance, he renders the beginning of the Adagietto from Symphony No. 5 as a piano ballad, with delicate

31 My analysis broadly follows Donald Mitchell's in his Gustav Mahler: Songs and Symphonies of Life and Death, 319.

32 It is tempting to speak of 'verse' and 'chorus' instead of ' $a$ ' and ' $b$ ' sections of each strophe; however, in the text the 'b' section is varied each time it occurs, so cannot be called a chorus properly speaking.

33 This is expressed in a personal e-mail dated 6 June 2006. 


\begin{tabular}{|c|c|c|c|c|c|c|c|c|c|c|c|c|c|c|c|c|}
\hline & \multicolumn{4}{|c|}{ Unit 1} & \multicolumn{4}{|c|}{ Unit 2} & \multicolumn{2}{|c|}{ Unit 3} & \multicolumn{6}{|c|}{ Unit 4} \\
\hline Bars & $1-18$ & $19-26$ & $27-38$ & $39-54$ & $55-138$ & $137-57$ & $158-65$ & $166-287$ & 288-302 & $303-22$ & $323-73$ & $374-81$ & $381-429$ & $430-58$ & $459-508$ & 509-72 \\
\hline $\begin{array}{l}\text { Mahler } \\
\text { text }\end{array}$ & & I, 1-3 & $\mathrm{I}, 4-5$ & I, 6-7 & II, 1-7 & II, 8-9 & III, 1-3 & III, 4-9 & & & & IV, $1-3$ & $\begin{array}{l}\text { IV, 4-6 } \\
\text { V, } 1-2\end{array}$ & $\mathrm{~V}, 3-5$ & VI, 1-4 & VI, 4 \\
\hline Keys & c & c & c & $\mathrm{c}-\mathrm{C}-\mathrm{c}$ & $\mathrm{F}-\mathrm{a}$ & $\mathrm{a}$ & $\mathrm{a}$ & $\mathrm{B}$, & $\mathrm{a}-\mathrm{g}$ & $\mathrm{c}$ & c & $\mathrm{c}$ & $\mathrm{c}$ & $\mathrm{F}$ & $\mathrm{C}$ & C \\
\hline Sections & Intro. & Rec. 1 & Aria 1 & Cont. & Aria 2 & Coda & Rec. 2 & Aria 3 & Trans. & Intro. & March & Rec. 3 & Aria $1^{\prime}$ & Aria $2^{\prime}$ & Aria 3' & Coda \\
\hline $\begin{array}{l}\text { Caine } \\
\text { text }\end{array}$ & $\begin{array}{l}\text { Psalm } \\
118: 5\end{array}$ & $\begin{array}{l}\text { El Male } \\
\text { Rahamim }\end{array}$ & $\begin{array}{l}\text { Psalm } \\
\text { 118:6 }\end{array}$ & & & & & & & & & $\begin{array}{l}\text { Psalm } \\
121: 1-4\end{array}$ & & & & \\
\hline
\end{tabular}

Note: shading indicates sections used by Caine. Keys are identified by upper-case letters for major and lower-case for minor.

Figure 1 Tabular overview of 'The Farewell' ('Der Abschied') from Das Lied von der Erde, following Mitchell, Gustav Mahler: Songs and Symphonies of Life and Death, 327-432.

\begin{tabular}{|c|c|c|c|c|c|c|c|c|c|c|c|c|}
\hline Section & \multicolumn{5}{|l|}{ A } & \multicolumn{3}{|c|}{ B (development) } & \multicolumn{4}{|c|}{ A (recapitulation) } \\
\hline Bars & 1 & 8 & 15 & 22 & 29 & 35 & 45 & 51 & 65 & 72 & 79 & 87 \\
\hline Motivic material & $\mathrm{a}$ & $\mathrm{b}$ & $\mathrm{a}^{\prime}$ & $\mathrm{b}^{\prime}$ & $a^{\prime \prime}$ & $\mathrm{b}$ & $\alpha$ & $\beta^{\prime}$ & $\beta^{\prime \prime}$ & $a^{\prime \prime \prime}$ & (b) & $a^{\prime \prime \prime \prime}$ \\
\hline Key & $\mathrm{A}-\mathrm{B}$ & $\mathrm{F}$ & $\mathrm{A}-\mathrm{B} b$ & $\mathrm{~F}$ & $\mathrm{~A} \sim$ & A & $\mathrm{C}-\mathrm{B}$, & $\mathrm{D} b$ & $\mathrm{~A}-\mathrm{B} b$ & $\mathrm{~A}-\mathrm{B}$ & $\mathrm{F}$ & A \\
\hline Instrumental solo & \multicolumn{2}{|c|}{ trumpet } & \multicolumn{2}{|l|}{ sax } & \multicolumn{2}{|c|}{ violin } & clarinet & trombone & \multicolumn{3}{|l|}{ piano } & chaos \\
\hline
\end{tabular}

Note: Greek letters signify substantially varied versions of material identified with Roman letters. Keys are identified by upper-case letters for major and lower-case for minor.

Figure 2 Instrumental solos in Caine's arrangement of Mahler's 'The Drunkard in Spring' ('Der Trunkene im Frühling') from Das Lied von der Erde. 
brushwork from the drums, dragging out Mahler's appoggiaturas and suspensions so that they sound like jazz harmonies; at the restatement of the theme in b. 10 the full ensemble takes over (Urlicht).

Instrumentation is often used to highlight the contrasts of the original. The contrasting instrumentation of the ' $a$ ' and 'b' phrases in 'The Drunkard in Spring' has already been mentioned. More radical is the arrangement of 'The Drummer Boy ('Der Tambourg'sell') from Des Knaben Wunderhorn (Urlicht): fitting the martial subject matter, the instruments are here confined to playing the stylized drum roll in particularly rough fashion (while ignoring its harmonic implications), whereas the vocal line, given to the vocalizing cantor, remains a cappella, in poignant contrast to the instrumental racket. But the most extreme example of this kind is 'Song of the Prisoner in the Tower' ('Lied des Verfolgten im Turm') from Des Knaben Wunderhorn (Dark Flame). Mahler's original cuts between the prisoner in the tower and 'the girl' (presumably his sweetheart), both parts taken by the same singer. Caine has the Bavarian actor Sepp Bierbichler defiantly shout out the prisoner's lyrics in German - 'Die Gedanken sind frei!' ('thoughts are free!') - accompanied by frantic drumming and heavily distorted electric guitar playing the vocal line without harmonic backing. The girl, meanwhile, is enunciated by Julie Patton, also speaking (in English) but in an ostentatiously 'girlish' voice, to an almost exaggeratedly lyrical duet of violin and piano (plus trumpet on the third occasion). While, in keeping with the aesthetics of the lied, the drama of the situation takes place in the imagination in the Mahler, Caine makes it explicit - the suggestion in the CD booklet that the scene takes place at the gates of a POW camp goes in the same direction. ${ }^{34}$

As indicated earlier, Dark Flame is generally more adventurous in terms of orchestration, one of the most haunting examples being 'The Lonely One in Autumn' ('Der Einsame im Herbst') from Das Lied von der Erde. Following his principle of returning the music to its roots, Caine here reflects the Chinese origin of the lyrics by transcribing the music for a duet of yangqin (a hammered dulcimer) and dizi (a transverse flute), complete with instrumental swapping, with the original text by Qian Qi being recited. ${ }^{35}$ Dark Flame also contrasts two arrangements of the same piece, 'Only Love Beauty' ('Liebst du um Schönheit') from Fünf Rückertlieder - one completely instrumental, the other for a vocalizing choir a cappella (only slightly twee).

On both CDs, the DJ-ing and electronics of DJ Olive and Danny Blume (electronics on Urlicht) play important roles, even though it is hard to describe adequately what those roles are. It was mentioned earlier how, in the film version, the electronic insect and bird sounds from 'Now Will the Sun' seem to reflect the scenery of the film that the music accompanies. This effect is obviously lost on the CDs; nevertheless, many of the sounds seem to locate the

34 This interpretation relies on an inaccurate translation, however: a Verfolgter is not a prisoner, but someone who is 'persecuted' and hence cannot be a POW (although the prison camp in Guantánamo Bay has flouted the distinction between POWs and political prisoners observed hitherto in civilized democratic countries).

35 The lyrics of Das Lied von der Erde are based on Hans Bethge's collection of classical Chinese poetry, Die chinesische Flöte (see Mitchell, Gustav Mahler: Songs and Symphonies, 157-500; Mitchell compares the different versions of all the poems that Mahler set). According to Lin Qiang (personal communication), Tong Qiang Chen's recitation here is stylistically appropriate but not quite of a professional standard in terms of verse rhythm and intonation. 
music in an imaginary space, rather than the neutral space suggested by the recording studio. In other words, the music is rendered concrete but at the same time it becomes slightly unreal inasmuch as the space suggested by the sounds is a virtual not a real one. In a similar way, electronic noises and turntabling fragments often defamiliarize the music, disrupting and slightly undermining the musical discourse, as if to signal that nothing is quite what it seems. This effect is particularly marked in the mock funeral march from Symphony No. 1: here the electronic distortion and eerie record fragments, slipping through the musical scenery like ghostly shadows, contribute considerably to the musical grotesquery, which is already an important element in the Mahler.

\section{Performance}

It is not only important which material is selected and how it is arranged but also how it is played; indeed, performance practice is perhaps the most revealing indicator of the musicians' relation to Mahler's music. Again, the first track on Urlicht, the funeral march from Symphony No. 5, is programmatic. What is striking is the vitality of the playing, which makes the orchestral original appear blurred and pompous by comparison. The jazz background of the players is surely an important factor here, as their playing is precise but not metronomic, alert but relaxed. Slight flaws such as the fudged trombone entry in b. 12 (the first entry after the opening trumpet fanfare) do not seem to matter at all (if they did, they would have been corrected: this is a studio recording, and the blemish cannot have been overlooked).

Yet the most revelatory moment is clearly the funeral march theme at b. 35 (see Example 1 for Mahler's original). What in Mahler is a stylized and hence domesticated version of a folkloristic tune, Mark Feldman returns to its roots, launching into the tune in the style of a fiddler, to the oom-pah of the other instruments (which Mahler was too polite to score, although his bass is clearly suggestive of one). Caine also adds percussion to the passage, which is likewise absent in Mahler, although it does occur when the passage returns in the recapitulation, if in mostly inaudible form. What is noteworthy here is that Feldman does not change the notes; it is purely his playing style that turns the music into something quite different - recalling Caine's remark about the performance of such tunes at Jewish weddings (at which the Uri Caine Ensemble would surely go down a storm).

A similar instance is provided by the third movement of Symphony No. 1. While the framing canon on the minor variant of 'Frère Jacques' is already a rather raucous rendition of what was a far from balanced and polished symphonic sound even in Mahler's original what with the murmuring cantor, the up-beat glissandos on the electric guitar, the uncanny electronic samples, the substitution of the original timpani by drums, and the generally coarse playing - the real revelation comes with the trio: where Mahler adds a sentimental and humorous note in a gently folkloristic idiom (see Example 2), Caine and his musicians launch into a full-scale Jewish wedding dance. Once again, the notes are from the score, although the musicians continue the klezmer idioms in instrumental solos 'on their own'.

What happens here, and in a number of other instances, is that the performers bring the subordinated voices contained in Mahler's music to the fore. This implies a reversal of values: 

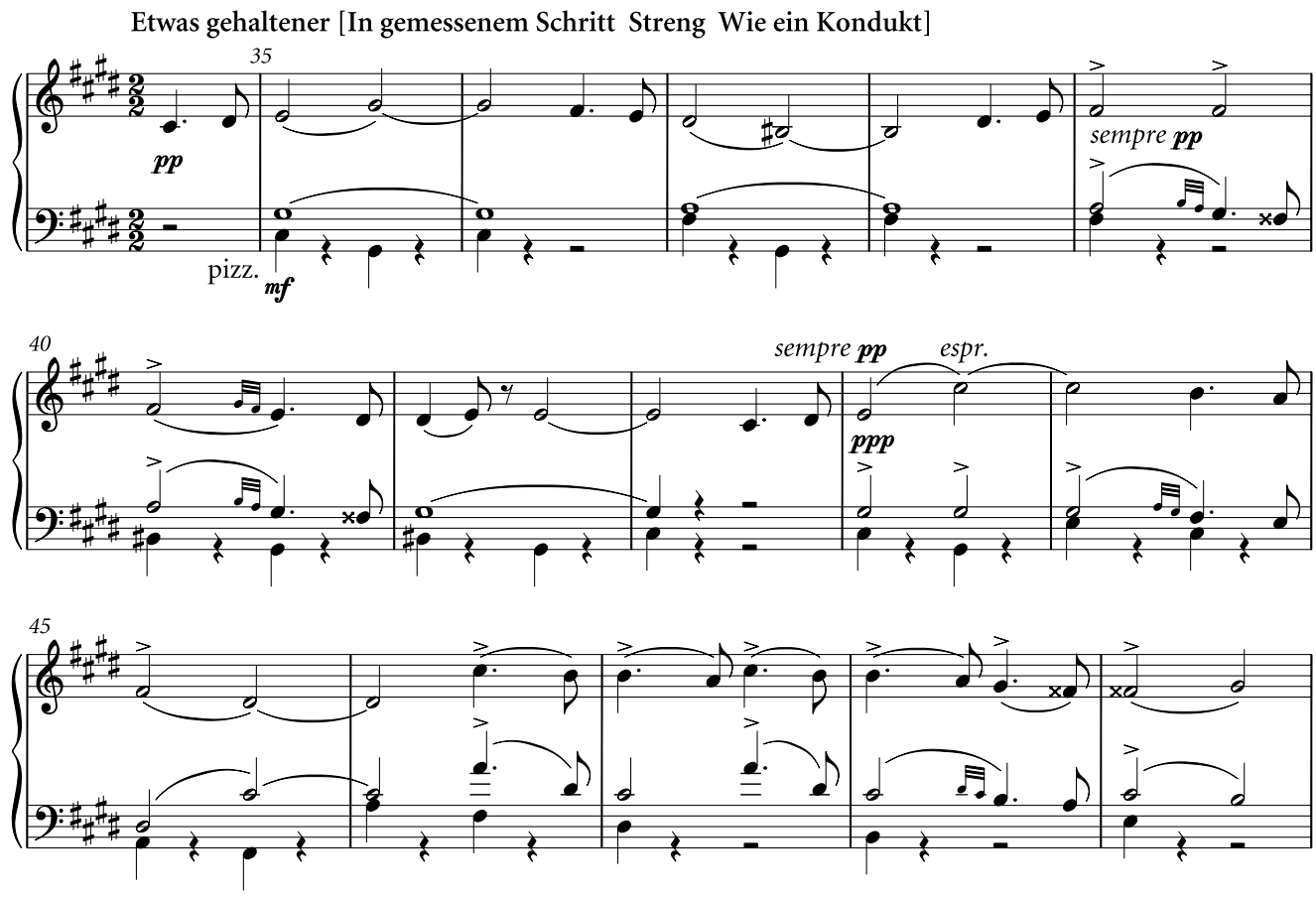

Example 1 Funeral march theme from Mahler, Symphony No. 5, 1st mvt, bb. 35-49.

in Mahler's music the slightly sentimental folk tunes, marches, and the like were often regarded as somewhat disreputable. It is only through their containment within an overall form and classical-modernist idiom that they could be 'elevated' to the status of art. From a discourse in their own right they have been reduced to a represented discourse, a sort of quotation whose presence can only be justified through the employment of the notion of 'irony' or 'parody' - in fact, the passage just referred to is annotated with 'Mit Parodie!' in the score (fig. 6). This is something of a commonplace in the Mahler literature; perhaps the most interesting instance is provided by Theodor W. Adorno, who gives a truly fascinating account of what he seems to regard as the dialectical function of 'banal' material, but who clearly seems at pains to find a rational explanation for its presence. ${ }^{36}$ It seems almost as if the

36 To give just a couple of examples of Adorno's treatment of folkloristic idioms in Mahler in his Mahler: a Musical Physiognomy, he mentions how, in the Scherzo of Symphony No. 2, 'the music makes itself vulgar' (7), and he speaks of a 'provocative alliance with vulgar music' (35-6). Here is an extended example of this dialectical approach to 'banality': 'Thanks to arrangements of this kind [rhythmic variations, such as in the Andante of Symphony No. 6, the Scherzo of No. 4, and the Kindertotenlieder], Mahler's themes lose the trace of banality that someone so disposed could criticize in some successions of intervals; usually in Mahler the charge of banality dogmatically isolates individual dimensions, blind to the fact that in him character, "originality," are defined not by single dimensions but only by their relationships to each other. That Mahler's procedure is exempted by its multidimensionality from the reproach of banality in no way denies the existence of banal elements or their function in the construction of the whole. What artifices such as these metrical devices bring about in banal musical material is the very refraction that integrates the banal into the art-work, which needs it as an autonomous agent, as an element of immediacy in the musical totality. Even the category of the banal is dynamic in Mahler; it appears in order to be paralyzed, not dissolved in the musical process without residue' (107-8). This is by far the most perceptive treatment of these elements in Mahler, but still, one cannot help feeling that Adorno is trying too hard. 
244 Heile Uri Caine’s Mahler

pp aber (rit.) 5 a tempo Ziemlich langsam

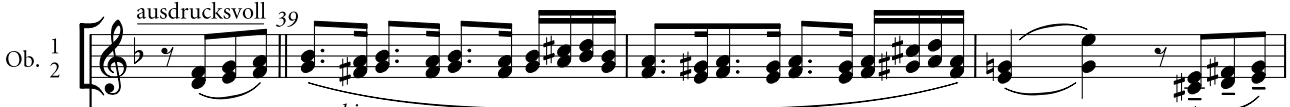
$\boldsymbol{p p}$ p subito
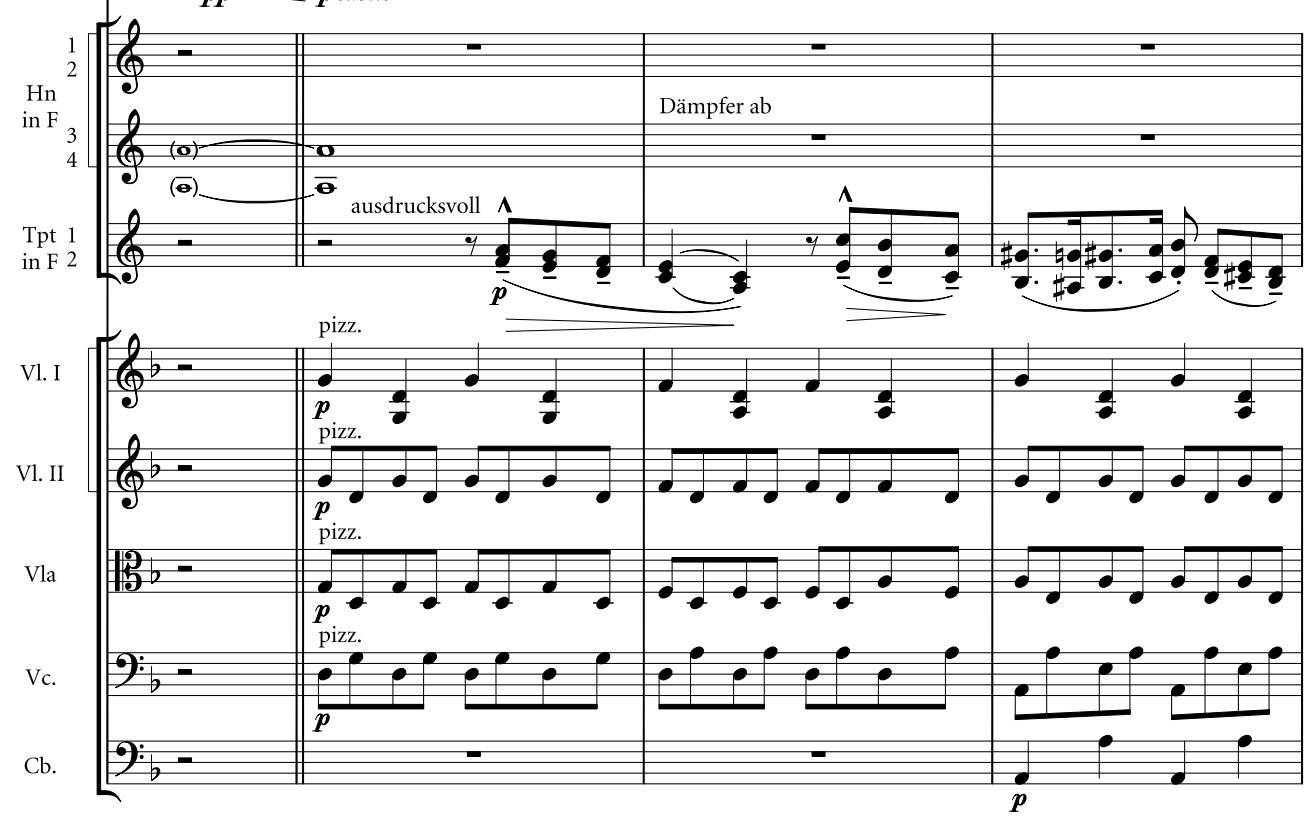

$\Longrightarrow$

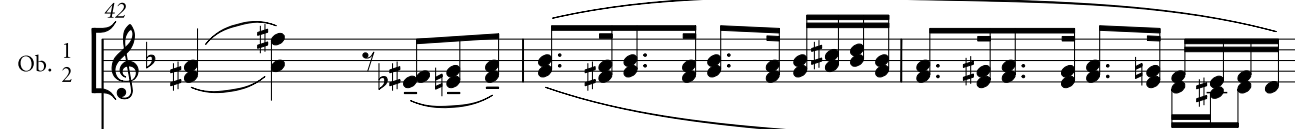

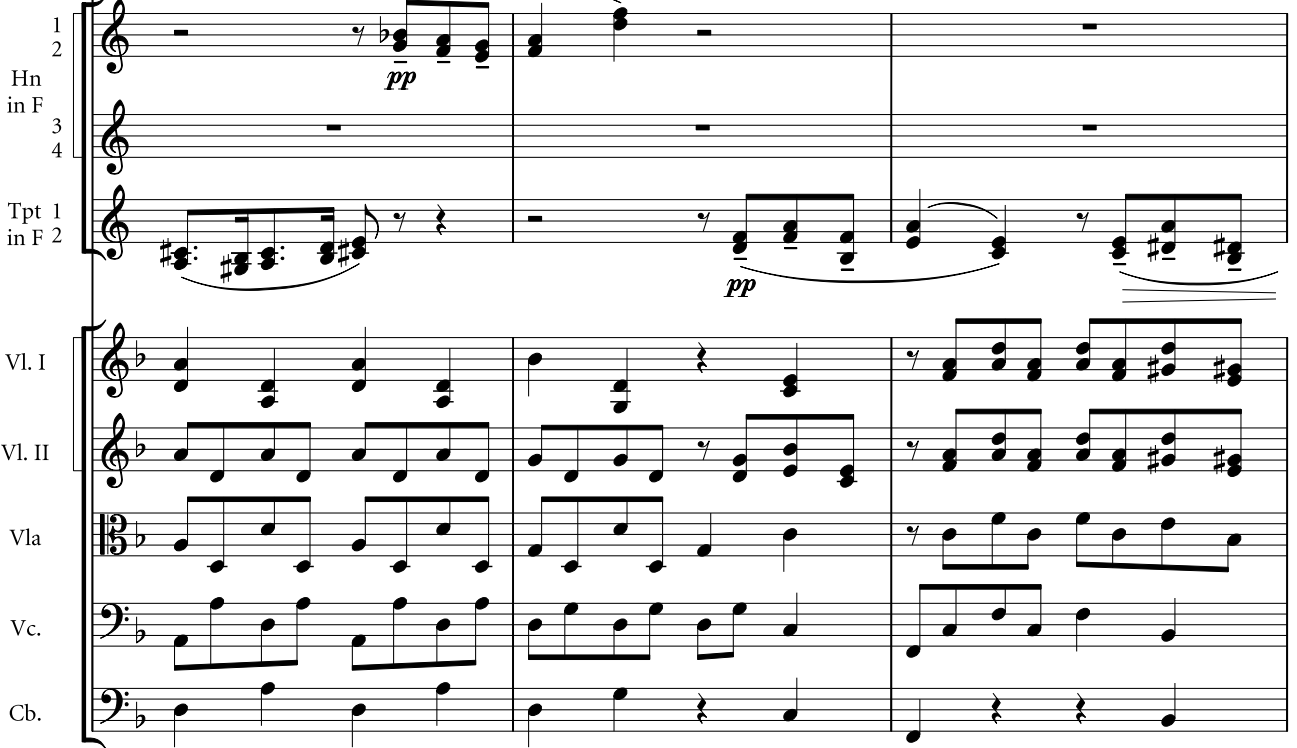

Example 2 Mahler, Symphony No. 1, 3rd mvt, bb. 39-50. 


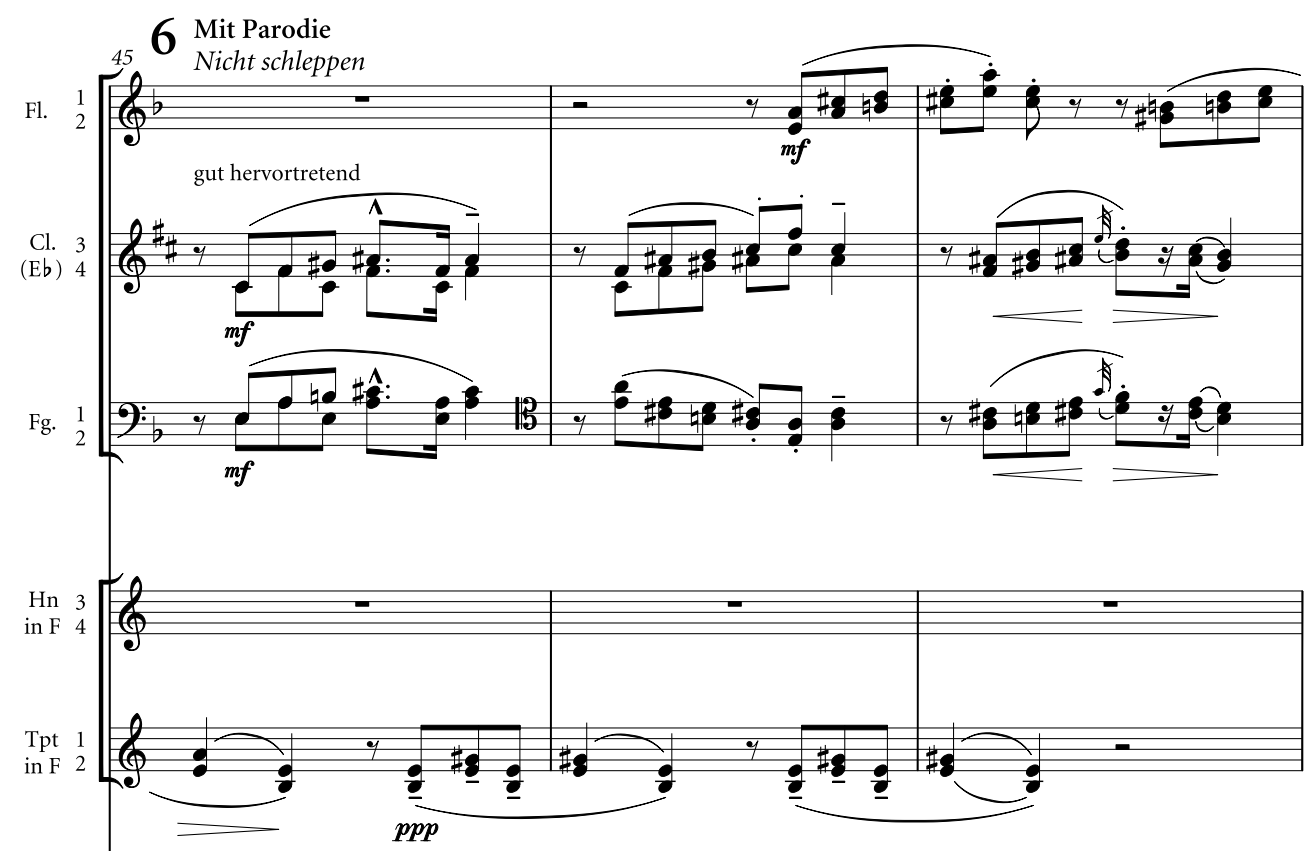

Die Becken sind an dieser Stelle an der grossen Trommel anzuhängen und Becken- und Trommelstimme sind von einem und demselben Musiker zu schlagen. Türkische

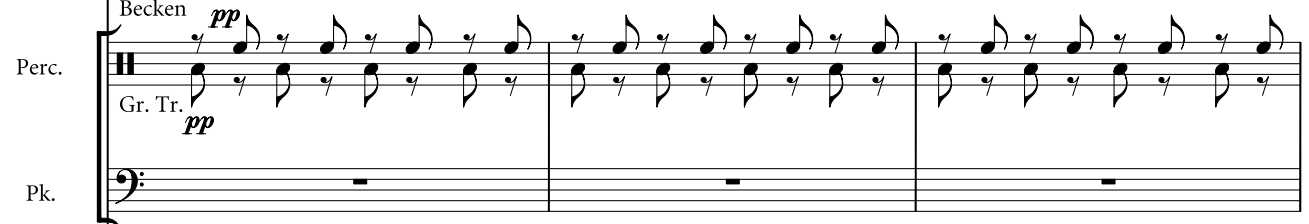

Mit Parodie

Vl. I

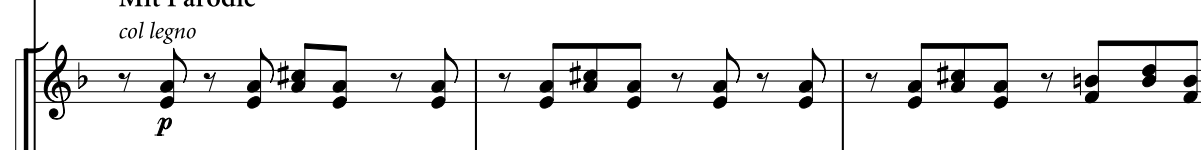

Vl. II

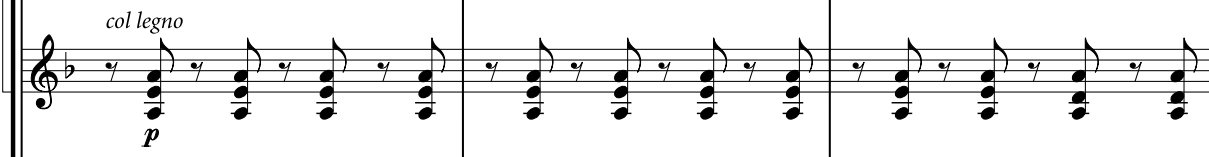

Vla

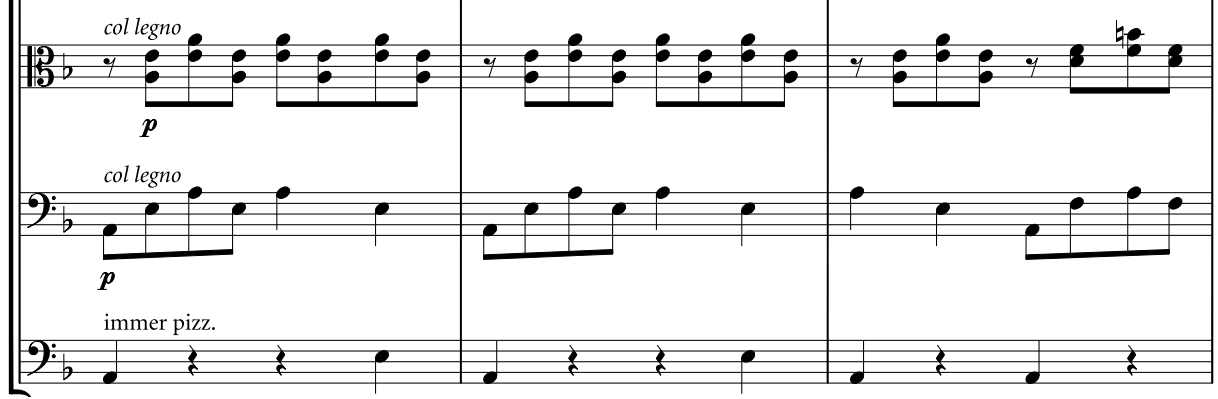

$\mathrm{Cb}$.

Example 2 continued. 
246 Heile Uri Caine’s Mahler

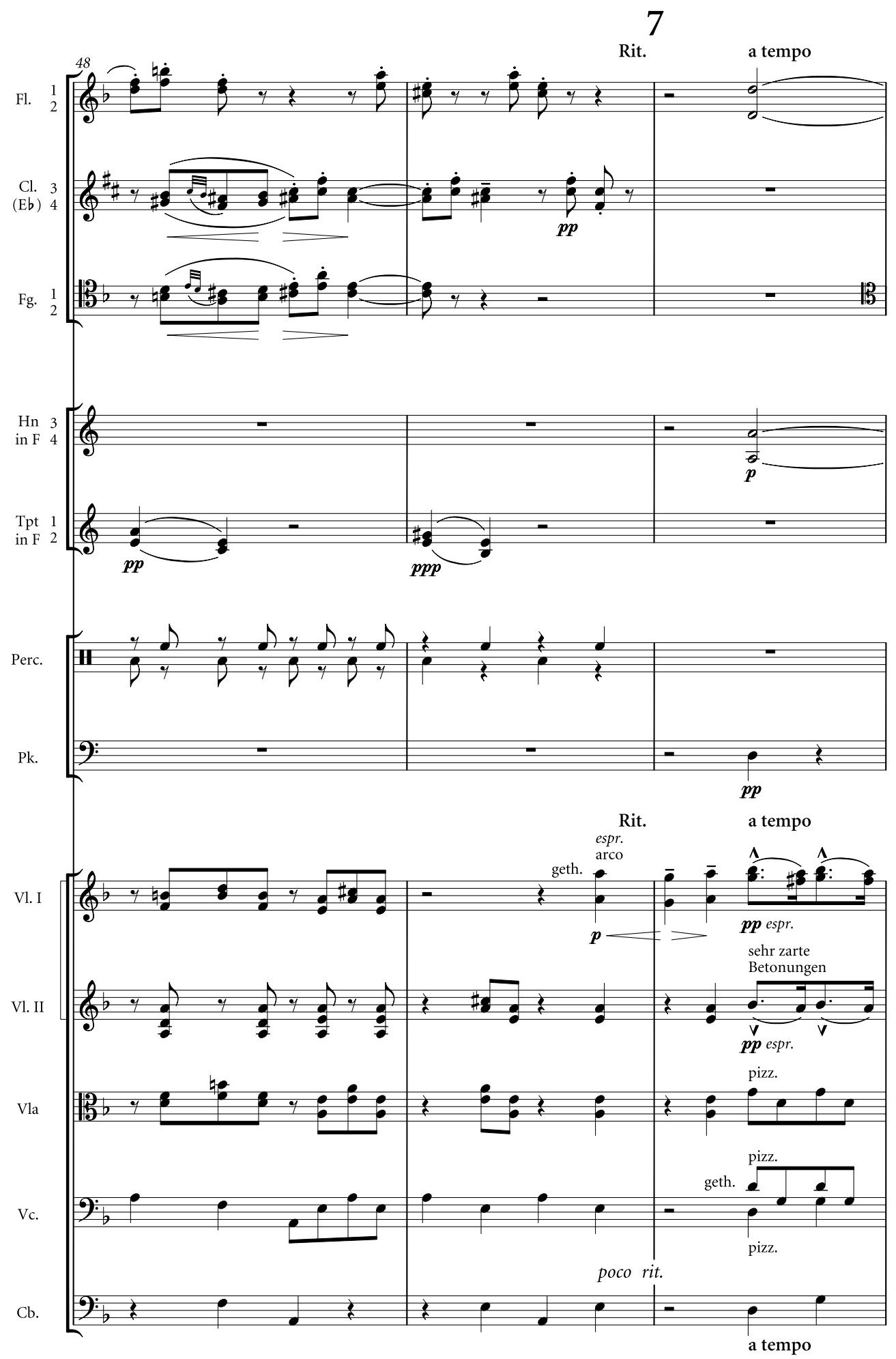

Example 2 continued. 
entire Mahler reception - with very few exceptions - is discouraging us from enjoying the folkloristic elements in Mahler for their own sake. ${ }^{37}$

Caine and his sidemen, by contrast, demonstrate a keen ear for the representation of otherness in Mahler's music, and they specifically value these voices within his discourse that are so often regarded with suspicion or disdain. In doing so, they seek to restore them to something like their former glory, to recapture the original quality of the music that has been lost in Mahler's classical stylization and/or typical performances of his music. However, this imaginary reconstruction is at least as much a simulacrum as Mahler's: the musicians do not attempt to reconstruct either the 'original music' that Mahler may have had in mind or its performance practice. Rather, their performance is one that restores some of the qualities of semi-improvised music making in a partly oral, vernacular tradition.

This carnivalistic reversal of the accepted hierarchies in Mahler's music is best described in terms of Bakhtinian dialogics. ${ }^{38}$ While, from a traditional perspective, the represented folkloristic discourses in Mahler's music are subordinated to his authorial discourse - what we may somewhat simplistically describe as his uninflected 'personal style' - Caine prioritizes the represented discourses. The value of Bakhtinian dialogics lies precisely in its destabilizing of conventional hierarchies: from a Bakhtinian perspective there is no preordained hierarchy between different discourses, and the Uri Caine Ensemble's predilection for what in conventional thinking is a secondary discourse is an important case in point. Also significant in this respect is the fact that Mahler's music is so dialogic in nature, which is to say that its 'polyphony' of musical idioms is a representation of the 'heteroglossia' of what may be called, for want of a better term, 'musical reality' - a product of Mahler's openness to the world around him (its music, but also, for example, the sounds of nature). It is precisely this dialogic quality that makes Mahler's music so apt for intertextual appropriations such as Caine's, but also, for instance, Berio's.

This predilection for the represented discourses in Mahler has wider implications. The trio from the third movement of Symphony No. 1 (see Example 2) is a case in point: Heinrich Berl had argued in 1923 that the whole movement represented 'purest Jewry' (basing his argument on vague notions of character rather than concrete stylistic features), and Leonard Bernstein used the passage at fig. 6 as his prime, and most celebrated, example of Mahler's musical Judaism, while Vladimir Karbusicky has confirmed that it is indeed of Jewish specifically Hassidic - origin. ${ }^{39}$ There are basically two schools of thought regarding the presence of Jewish elements in Mahler's music, one stressing Mahler's role in the canon of German symphonic music and thus minimizing all 'extraneous' elements, and another

37 It is beyond the scope of this article to provide an account of the treatment in the Mahler literature of the composer's allusions to folkloristic elements. For a discussion of this literature see Karbusicky, 'Gustav Mahlers musikalisches Judentum'; see also the superb study of these influences in his earlier Gustav Mahler und seine Umwelt.

38 I am referring specifically to Bakhtin's Problems of Dostoevsky's Poetics, The Dialogic Imagination, and Rabelais and his World. For an introduction to musical applications of Bakhtin's theories see, for instance, Heile, "'Transcending Quotation"', and 'Kagel, Bachtin und eine dialogische Theorie musikalischer Intertextualität'; Hatten, Musical Meaning in Beethoven; and Korsyn, 'Beyond Privileged Contexts'.

39 For Berl see Painter, 'Jewish Identity and Anti-Semitic Critique', 187; Bernstein, 'Who Is Gustav Mahler?'; and Karbusicky, 'Gustav Mahler's musikalisches Judentum'; cf. also Draughon and Knapp, 'Gustav Mahler and the Crisis of Jewish Identity'. 
(smaller one) drawing attention to such marginalized idioms. ${ }^{40}$ The position of Uri Caine's ensemble in this debate is obvious: never before has Mahler sounded so Yiddish! The musicians' experience in the performance practice of Jewish musics - authentic and apocryphal - pays rich dividends here. This consistent 'klezmerizing' of the folkloristic elements in Mahler's music is one of the most noticeable features of Caine's Mahler albums. It is not least because of this that Caine is successful where so many other jazz adaptations of classical music fail: for, instead of treating Mahler's works in a reverential way as a generic example of a reified notion of 'classical music', his version is a genuine and radical reinterpretation that is sensitive to what is distinctive about the composer's music, allowing us to hear it in a new way (even when it is performed in traditional fashion). In other words, he has something original and individual to say about Mahler's music.

It is also through his performance practice that Caine stakes his claim for Mahler: he situates Mahler as a Jewish voice within the highly contested territory of fin-de-siècle Central Europe, and in referring to Mahler he situates himself within American jazz culture, namely, by constructing a specifically Jewish tradition within jazz. It should be noted, though, that not all the music given the Yiddish treatment is likely to be of Jewish origin: the already mentioned march theme from the first movement of Symphony No. 5 is a case in point.

But it is not only the Jewish (or faux-Jewish) elements in Mahler that are returned to their (putative) roots. I have already referred to the Chinese recitation of 'The Lonely One in Autumn' (Dark Flame): here the arrangement for dizi and yangqin uncovers the chinoiseries in Das Lied von der Erde. Similarly, many of the manifold stylistic idioms that commentators find in Caine's music are actually motivated by Mahler's originals, even where Mahler could not have consciously represented them. For instance, the denial expressed in 'I Often Think They Have Merely Gone Out' ('Ich denke oft, sie sind nur ausgegangen', Kindertotenlieder) from Urlicht is heightened by a laid-back, Afro-Cuban lilt. While this is unlikely to have been on Mahler's mind, the constant cross-rhythms in the cellos, at times assimilating the rumba clave $(3+3+2)$, were clearly enough to provoke that association for Caine. This brings to mind Berio's observation (regarding his use of the third movement from Mahler's Symphony No. 2 in the third movement of his own Sinfonia) that Mahler's work not only 'seems to carry all the weight of the last two centuries of musical history', but also to contain something like the germ for future music. ${ }^{41}$ In Bakhtinian terms, it is dialogic through and through.

40 Apart from the material cited earlier, cf. Pecker Berio, 'Mahler's Jewish Parable', and Kravitt, 'Mahler, Victim of the "New” Anti-Semitism'. Karbusicky's 'Gustav Mahlers musikalisches Judentum' contains a neat summary of the debate: his condemnation of those who have denied or suppressed the Jewish elements in Mahler's music is only weakened by his neglecting to mention that his own earlier Gustav Mahler und seine Umwelt is equally guilty of this omission. Nevertheless, it is unfortunate that his contribution has not received the attention it undoubtedly deserves.

41 In the full quotation Berio speaks of the Scherzo from Mahler's Symphony No. 2 acting as 'a generative source [for the third movement of his Sinfonia], from which are derived a great number of musical figures ranging from Bach to Schoenberg, Brahms to Stravinsky, Berg to Webern, Boulez, myself and others' (quoted from the composer's programme note in the CD booklet for Sinfonia, Eindrücke). See also Osmond-Smith, Playing on Words. 


\section{Composition and improvisation}

While some of the stylistic variety of Caine's work is thus due to the ensemble's performance of Mahler, the added material, which is the product of improvisation, provides an opportunity for widening the stylistic horizon still further. ${ }^{42}$ In dealing with contemporary jazz, we must take care to avoid the still rather common assumption of a dichotomy between improvisation and composition. Caine's work on Mahler is no exception: what the musicians seem to practise are all manner of combinations between completely prearranged material and improvisation - free collective improvisation through solo improvisation to improvisation with prearranged elements (notably the harmonic structures taken from Mahler, but also riffs, modes, motifs, or, simply, specific idioms).

In analysing Caine's improvised responses to Mahler's music, two factors have to be taken into account. The first concerns the distinction between vertical and horizontal additions to Mahler's music, that is, between, on the one hand, music that is improvised simultaneously with Mahler's original, and, on the other, material that is inserted in between sections adapted from Mahler. The second factor concerns the relation between the improvised music and Mahler's composition. For instance, I mentioned above that in the trio section in the mock funeral march of Symphony No. 1 the musicians continue the Hassidic idiom (if we follow Karbusicky) in what seem to be collective improvisations (with soloistic roles). In this case, the improvisation is horizontal in that at a specific moment the musicians depart from Mahler's music, but it is idiomatically so closely related to it that the exact moment of departure may not be perceptible for listeners without knowledge of the original or a score to hand. Here the musicians are evidently playing with the distinctions between 'original' and 'emulation' and between 'composition' and 'improvisation': several times the music disintegrates into chaos only to 'pick itself up again'. It would appear that the factor constraining the collective improvisation - if that is what it is - is style: this is a persuasive klezmer performance, but presumably not of a specific piece.

'I Went Out This Morning over the Countryside' (Urlicht), which has also been mentioned, is a related example. Here Caine has arranged the material as a classic jazz piano trio, not much different from the way his trio would perform a jazz standard. The piano solo following the opening strophe is a horizontal addition (inasmuch as Caine's solo departs from the original); but it seems related, this time, however, not idiomatically but harmonically and, to a lesser extent, motivically: in traditional jazz practice, Caine improvises on Mahler's harmonies, using some of Mahler's motifs from time to time. ${ }^{43}$ This exemplifies Caine's claim that his practice is akin to Charlie Parker improvising on an Irving Berlin tune (see above).

'The Drunkard in Spring' presents an example of (mostly) horizontal additions that at first seem unrelated to the Mahler original. I have pointed out above how Caine arranges a series of solos into an overarchingly strophic scheme: these solos are stylistically opposed to

42 In a telephone conversation on 7 June 2006 Caine confirmed that all the 'non-Mahler' material is improvised and that there is no other composed material.

43 In the telephone conversation of 7 June 2006 Caine confirmed that improvisations are based on Mahler's harmonies. This is not always as easy to hear as in the present example. 
the Mahler, although they respect its harmonic framework. The impression is of a frantic and often surprising succession of contrasting styles and tempos, from Dave Douglas's post-bopinfluenced solo at the beginning, through Dave Binney's ecstatic shrieks, to the bossa-nova backing of Feldman's solo and the free-jazz-inspired ending (in all these cases the backing must have been to a certain extent prearranged). 'The Drunkard in Spring' also features a vertical addition, namely, the soul vocals and electric guitar added to the 'b' section of each strophe. This is clearly one of the most eclectic pieces in the album: the range and combination of styles and idioms are remarkable, and the seeming ease with which the musicians negotiate the ruptures is truly astonishing. But one should be careful not to overstate this point: all idioms used fall within the overall sphere of contemporary jazz (a very flexible category, to be sure), and the contrasts are positively mild compared with such examples as John Zorn's Naked City. ${ }^{44}$ This type of horizontal addition of material is perhaps the most frequent on both albums; one further example that should be mentioned is Bensoussan's extended solo in what appears to be a North African style in 'The Drummer Boy' (Urlicht), in which he accompanies himself on hand-drums to which Joey Baron adds more density.

Vertical addition of material is rarer. In one instance Mark Feldman improvises over the opening chorale, played by winds, of the fourth movement, 'Urlicht', of Symphony No. 2: he starts with slight ornamentations but gradually builds up towards ever more frenzied arpeggiations and passage-work. But the more radical simultaneous juxtapositions of material are generally to be found on Dark Flame. Perhaps the most striking example is 'Two Blue Eyes' ('Die zwei blauen Augen von meinem Schatz') from Lieder eines fahrenden Gesellen. After the first strophe (b. 17) there is a break, and Caine starts soloing with a trio backing in a contemporary post-bop style (but using some of the melodic material from the original). While he is playing, the other instruments enter with the next strophe exactly where they had left off, creating two separate layers in a manner reminiscent of Charles Ives, although the phenomenon occurs, albeit in less radical form, in Mahler as well.

Finally, there are hybrid passages using a combination of Mahler-derived and improvised material in ways that subvert the composition-improvisation dichotomy. The most conspicuous instances of this occur in 'The Farewell' (Urlicht). I have already mentioned the cantor's extended recitation when, in the original, there are short recitatives (bb. $19 \mathrm{ff}$. and 374 ff., respectively). So the music is not directly derived from Mahler, yet it is functionally analogous: Bensoussan's recitation is similar in kind to the recitative in the original and it serves a similar purpose in the overall musical narrative. Moreover, as I have pointed out, the harmonies alternate between $\mathrm{C}$ minor and $\mathrm{F}$ minor in $6 / 4$ position in a similar way to the Mahler.

\section{Text and song}

I have so far ignored the texts of Mahler's originals and what the singers are singing. In keeping with jazz practice, the vocal line of Mahler's original is most often played instrumentally or, on occasion (as in 'The Drummer Boy' and 'I Often Think They Have Merely Gone

44 CD, Elektra/Nonesuch 7559-79238-2. 
Out' from Urlicht), sung as vocalise or hummed. In fact the only occasion when lyrics are sung on Urlicht is in 'Der Abschied', in which Bensoussan intones Psalms 118 and 121 in Hebrew, as well as, in the first recitative, El Male Rahamim, the Jewish Prayer for the Dead texts that obviously accord with the funereal theme of the original. ${ }^{45}$ The effect of this re-texting is striking, and the consequences are considerable. Caine raises the chthonic references of the original to the level of formal liturgy, and in doing so seems to ask the question of whose farewell is being mourned. What was, in Mahler, a meditation on death and the afterlife on a personal, subjective level, Caine seems to transform into a lament for the fate of the Jews in the Holocaust. The music becomes an emblem of the now lost world of Central European Jewry, of which Mahler was such a prominent representative. This exemplifies to what extent Caine's music is a reflection on Mahler, from the perspective of another place and time, rather than a straightforward rendition of it: for Mahler the music could obviously not have had such associations; nevertheless, they are clearly legitimate.

On the whole, Dark Flame betrays a much greater interest in the texts, but, again, there is a clear dissociation between the enunciation of text and singing. Apart from Bierbichler's rather grating singing of a short passage at the end of 'Song of the Prisoner', all the lyrics that are used are spoken; singing, when it does occur, is wordless. It appears as if Caine wanted to avoid a 'naive' and traditional listening situation with respect to the songs. This distancing technique is also apparent in the use of different languages, sometimes, as in 'Song of the Prisoner', in one song. Dark Flame contains spoken text in the original German, English, Chinese, and Hebrew. Not all the text is from the original, however: there are free variations on the lyrics by Julie Patton in 'Dark Flame' and 'Two Blue Eyes', poems in English and Hebrew by Caine's mother Shulamith Wechter Caine, and a poetic reflection on Mahler's relation with his wife Alma and his encounter with Freud by Sadiq Bey on 'Labor Lost' - all spoken by the poets. It is impossible to do justice to the complex and evocative poetry and its relation to the music within the remit of this article; yet the overall effect is, once again, of a meditation and commentary on Mahler's music - more conspicuously so than in the case of Urlicht.

\section{Conclusion: Mahler, Jazz, and Constructions of Jewish Identity}

All in all, then, Caine's background in jazz comes to the fore from time to time, most conspicuously in 'I Went Out This Morning' (Urlicht) and 'Two Blue Eyes' (Dark Flame). But jazz is not necessarily more prominent than other idioms such as klezmer or Latin. More important, perhaps, than audible stylistic signifiers are the arrangements and the kind of music making represented on the albums. Caine's preference for strophic or ternary forms and the way he inserts solos at specific formal junctures clearly reveal the influence of jazz practice, and the subtle interaction between composed material and various types of improvisation as well as the astonishing versatility of the musicians and

45 I should like to thank Naomi Tadmor for her help with the Hebrew and with the cultural signification of El Male Rahamim. 
the whole style of playing are unmistakable characteristics of jazz. In other words, whether the result can unequivocally be described as jazz may be controversial, but only a jazz musician would arrange the material in this way and only jazz musicians would perform it like this.

In some ways, though, the question of whether or not this is jazz is artificial: jazz has throughout its history been a hybrid, dialogic style, incorporating all manner of different idioms and influences, and it is this history of inclusive heteroglossia, rather than a purportedly pure, monologic tradition centring on the golden age from New Orleans to bebop, that Caine embraces - and emphatically so. ${ }^{46}$ His recourse to classical music, which, as we have seen, forms a part of an important lineage within the history of jazz, should likewise not be regarded as a departure from jazz but as a commitment to the pluralistic identity that, in slightly paradoxical fashion, is jazz's very essence. It would be short-sighted to regard this as a denigration of jazz's African-American roots: as pointed out before, Caine has also paid homage to many of the African-American jazz greats, and he continues to do so. Nevertheless, rather than imitating African-American musicians, whose experiences have often been radically different, Caine incorporates other traditions and identities within the overall discourse of jazz. In addition to this, his collaborators (including African-American musicians such as Don Byron), who are all schooled in various musical traditions and are more or less intimately connected with the radical eclecticism practised at the Knitting Factory, add their individual voices to the dialogue.

For these reasons, it would be too simple to regard the stylistic pluralism practised in Caine's Mahler projects as little more than the reflection of a postmodernist Zeitgeist. ${ }^{47}$ There is more going on in his music than the surrendering of subjective identity to a Jamesonian depthless manipulation of attractive sonic surfaces, all readily available in consumer society and distinguishable only by relative exchange value and claims to prestige. ${ }^{48}$ Rather, what Caine seems to be attempting is to construct a subjectivity by negotiating different identities. As we have seen, his music reconciles a deep attachment to the classical repertoire of his instrumental and compositional training with a love of jazz. Likewise, his idea of jazz complements the commitment to its African-American progenitors with a stake for ownership of a specifically Jewish identity within it. All these different traditions are referenced with admirable clarity in his music: his engagement with the European classical tradition creates linkages with a long list of precursors within jazz, and his uncovering or inventing of Jewish

46 For an (admittedly somewhat one-sided) account of the attempt to preserve a 'pure' jazz tradition see Nicholson, Is Jazz Dead?, esp. 23-76. For an attempt to integrate Caine into a wider historical tradition of jazz see Cotro, 'La Résurgence'.

47 Cf. Malone's thoughtful review of Dark Flame in JazzTimes: 'It's all well and good to talk of postmodern maneuvers and profusions of genres and even relentless experimentation when discussing Uri Caine's takes on the songs of Gustav Mahler, 1997's Urlicht/Primal Light and the new Dark Flame. But those vague catchphrases don't really describe what Caine is doing with (or to, or near) Mahler's music. [. . . Caine isn't simply smashing disparate styles up against one another and relying on the cognitive disjunct to stir the listener. Even when "Two Blue Eyes" shifts from lumbering accompaniment to synagogue cantor Aaron Bensoussan to a hot jazz workout and then to original poetry by Shulamith Wechter Caine, the pain and loss in Mahler's song and Caine's interpretation unifies it all. Every choice Caine makes serves a clear-eyed imaginative vision of the possibilities of Mahler's music, no matter how complicated the execution of that vision becomes.' 
roots in Mahler's music finds its model in John Zorn and his idea of 'Radical Jewish Culture', just as many of Caine's artistic procedures have been foreshadowed by musicians such as Bill Frisell. Last, but not least, his engagement with Mahler is not a neutral performance but a radical reinterpretation from a specific intersubjective perspective that allows us to hear Mahler's music in new ways and to situate it in the cultural and ideological cross-currents of his age. Specifically, the apparent references to the Holocaust in 'Der Abschied' illustrate the transhistorical dimension of Caine's work.

While Caine thus clearly draws from a variety of traditions, his selection of styles is anything but indiscriminate. More importantly, his music does not simply blend styles in a bland mishmash, or represent 'exotic' idioms as deviations from the position of a monologic master-discourse, but is genuinely dialogic and non-hierarchic, creating exciting juxtapositions and new forms of hybridity. In the same way, his ardent embrace of a Jewish legacy in Mahler does not prevent him from recognizing other traditions, such as the chiefly AfricanAmerican heritage of jazz or the (faux-)Chinese elements in Mahler.

Likewise, the subjectivity he constructs is inclusive rather than exclusive, but that does not render it non-committal vis-à-vis the different identities to which it is indebted. Rather than referring to a loss of subjectivity or decentred subjectivity, one should therefore speak of dialogic subjectivity, again in Bakhtin's sense. What this illustrates, then, is that the idea of a loss of subjectivity in the globalized postmodern world seems itself to be predicated on an outdated conception of subjectivity that takes the commitment to a single unitary identity - national, racial, sexual, and religious - for granted. What Caine demonstrates, by contrast, is that the loss of such unitary identities does not necessarily lead to a random collection of essentially empty identity signifiers, but that different identities can exist side by side and in dialogue with one another without a concomitant loss of attachment. This is what makes Caine's music a valuable model for the music and culture of the twenty-first century.

\section{Discography, Filmography}

Blue Wail. Uri Caine Trio. CD, Winter \& Winter 910 034-2. 1998.

Dark Flame. Uri Caine Ensemble, vocalists, and choir. CD, Winter \& Winter 910 095-2. 2003.

The Diabelli Variations. Uri Caine (piano) and Concerto Köln. CD, Winter \& Winter 910 086-2. 2002.

The Goldberg Variations. Uri Caine Ensemble. CD, Winter \& Winter 910 054-2. 2000.

Gustav Mahler at Toblach: I Went Out This Morning over the Countryside. Uri Caine Ensemble. CD, Winter \& Winter 910046-2. 1999.

Ich bin der Welt abhanden gekommen/Detaching from the World. Director, Franz Winter. DVD, Winter \& Winter 915 003-7. 2005.

Live at the Village Vanguard. Uri Caine Trio. CD, Winter \& Winter 910 102-2. 2004.

Moloch: Book of Angels Volume 6 (John Zorn, Masada Songbook II). Uri Caine (solo piano). CD, Tzadik 7360. 2006. Rio. Uri Caine Ensemble and vocalists. CD, Winter \& Winter 910 079-2. 2001.

Robert Schumann/Love Fugue. Uri Caine Ensemble, La Gaia Scienza. CD, Winter \& Winter 910 049-2. 2000.

Shelf-Life. Uri Caine and Bedrock. CD, Winter \& Winter 910 112-2. 2005.

The Sidewalks of New York - Tin Pan Alley. Uri Caine Ensemble and vocalists. CD, Winter \& Winter 910 038-2. 1999.

Solitaire. Uri Caine (solo piano). CD, Winter \& Winter 910 075-2. 2001.

Sphere Music. Uri Caine Ensemble. CD, JMT 514 007-2. 1993. Reissued, Winter \& Winter 919 064-2. 2005. 
Toys. Uri Caine Ensemble. CD, JMT 514 022-2. 1995. Reissued, Winter \& Winter 919 077-2. 2002.

Uri Caine Ensemble Plays Mozart. Uri Caine Ensemble. CD, Winter \& Winter 910 130-2. 2006.

Urlicht/Primal Light (Gustav Mahler/Uri Caine). Uri Caine Ensemble. CD, Winter \& Winter 910 004-2. 1997.

Wagner e Venezia. Uri Caine Ensemble. CD, Winter \& Winter 910 013-2. 1997.

Zohar: Keter. Uri Caine, Aaron Bensoussan, Zohar Ensemble. CD, Knitting Factory 236. 1999.

\section{Bibliography}

Adorno, Theodor W. Mahler: a Musical Physiognomy, trans. Edmund Jephcott. Chicago and London: University of Chicago Press, 1992.

Ake, David. Jazz Cultures. University of California Press, 2002.

Bakhtin, Mikhail. Rabelais and his World. Cambridge, MA: MIT Press, 1968.

- Problems of Dostoevsky's Poetics, ed. and trans. Caryl Emerson, Introduction by Wayne C. Booth. Manchester: Manchester University Press, 1984.

- The Dialogic Imagination: Four Essays, ed. Michael Holquist, trans. Caryl Emerson and Michael Holquist. Austin: University of Texas Press, 1992.

Barry, Barbara R. 'The Hidden Program in Mahler’s Fifth Symphony’. Musical Quarterly 77/1 (1993), 47-66.

Berio, Luciano. Liner notes for Sinfonia, in Berio, Sinfonia, Eindrücke. CD, Apex 8573 89226-2. 2006.

Bernstein, Leonard. 'Who Is Gustav Mahler?'. Facsimile edited typescript for 'Young People's Concert', 7 February 1960. The Leonard Bernstein Collection, ca. 1920-1989. American Memory, Music Division, Library of Congress. <http://memory.loc.gov/ammem/lbhtml/lbhome.html> (accessed 19 November 2007).

Blumenthal, Bob. 'Third Stream from the Source: Gunther Schuller'. JazzTimes (February 2001), 54.

—. 'Worldly Music: Don Byron and Uri Caine'. JazzTimes (February 2001), 51-3.

Brubeck, Darius. '1959: the Beginning of Beyond', in The Cambridge Companion to Jazz, ed. Cooke and Horn. 177-201.

Caine, Uri. Uri Caine website, <http://www.uricaine.com> (accessed 19 November 2007).

Cooke, Mervyn. 'Jazz among the Classics, and the Case of Duke Ellington', in The Cambridge Companion to Jazz, ed. Cooke and Horn. 153-73.

— and David Horn, eds. The Cambridge Companion to Jazz. Cambridge: Cambridge University Press, 2002.

Cotro, Vincent. 'La Résurgence du passé dans le jazz contemporain: une problématique post-moderne?'. Revue de Musicologie 91/2 (2005), 425-54.

Draughon, Francesca, and Raymond Knapp. 'Gustav Mahler and the Crisis of Jewish Identity'. ECHO: a Music-Centred Journal 3/2 (2001). <http://www.echo.ucla.edu/volume3-issue2/knapp_draughon/knapp_ draughon1.html> (accessed 19 November 2007).

Gilbert, Mark. 'Byron, Don'; 'Caine, Uri', in The New Grove Dictionary of Music and Musicians, 2nd edn, ed. Stanley Sadie and John Tyrrell. London: Macmillan, 2001. Version at Grove Music Online, ed. Laura Macy. <http:// www.grovemusic.com> (accessed 19 November 2007).

Hatten, Robert. Musical Meaning in Beethoven: Markedness, Correlation, and Interpretation. Bloomington: Indiana University Press, 1994.

Heile, Björn. 'Kagel, Bachtin und eine dialogische Theorie musikalischer Intertextualität', in Musiktheorie zwischen Historie und Systematik: 1. Kongreß der deutschen Gesellschaft für Musiktheorie, ed. Felix Diergarten, Ludwig Holtmeier, and Michael Polt. Saarbrücken: Wißner, 2004. 62-9.

—. " "Transcending Quotation”: Cross-Cultural Musical Representation in Mauricio Kagel's Die Stücke der Windrose für Salonorchester'. Music Analysis 23/1 (2004), 57-85.

Hobsbawm, Eric. 'Benefits of Diaspora: Eric Hobsbawm on the Jewish Emancipation'. London Review of Books 27/20, 20 October 2005, pp. 16-19.

Joyner, David. 'Analyzing Third Stream'. Contemporary Music Review 19/1 (2000), 63-87.

Karbusicky, Vladimir. Gustav Mahler und seine Umwelt. Darmstadt: Wissenschaftliche Buchgesellschaft, 1978.

_. 'Gustav Mahlers musikalisches Judentum'. Hamburger Jahrbuch für Musikwissenschaft 16 (1999), $179-207$. Eng. trans. 'Gustav Mahler's Musical Jewishness', in Perspectives on Gustav Mahler, ed. Jeremy Barham. Aldershot: Ashgate, 2005. 195-217.

Kennedy, Gary W. 'Zorn, John', in The New Grove Dictionary of Jazz. Version at Grove Music Online, ed. Laura Macy. <http://www.grovemusic.com> (accessed 19 November 2007).

Korsyn, Kevin. 'Beyond Privileged Contexts: Intertextuality, Influence, and Dialogue', in Rethinking Music, ed. Nicholas Cook and Mark Everist. Oxford: Oxford University Press, 1999. 55-72.

Kravitt, Edward F. 'Mahler, Victim of the "New" Anti-Semitism'. Journal of the Royal Musical Association 127 (2002), 72-94. 
Malone, Andrew Lindemann. Review of CD, Uri Caine/Gustav Mahler, Dark Flame. JazzTimes (April 2004). $<$ http://www.jazztimes.com/reviews/cd_reviews/detail.cfm?article_id=14553> (accessed 19 November 2007). - Review of CD, Uri Caine Trio, Live at the Village Vanguard. JazzTimes (October 2004). <http:// www.jazztimes.com/reviews/cd_reviews/detail.cfm?article_id=14997> (accessed 19 November 2007).

Mehldau, Brad. 'Brahms, Interpretation and Improvisation'. JazzTimes (February 2001), 55-6, 180-1.

Mitchell, Donald. Gustav Mahler, Vol. 2: The Wunderhorn Years: Chronicles and Commentaries. London: Faber, 1975.

- Gustav Mahler: Songs and Symphonies of Life and Death: Interpretations and Annotations. London: Faber, 1985.

Nicholson, Stuart. 'Fusions and Crossovers', in The Cambridge Companion to Jazz, ed. Cooke and Horn. 217-52.

- Is Jazz Dead? (Or Has It Moved to a New Address). New York: Routledge, 2005.

Osmond-Smith, David. Playing on Words: a Guide to Luciano Berio's 'Sinfonia'. London: Royal Musical Association, 1985.

Painter, Karen. 'Jewish Identity and Anti-Semitic Critique in the Austro-German Reception of Mahler, 1900-1945', in Perspectives on Gustav Mahler, ed. Jeremy Barham. Aldershot: Ashgate, 2005. 175-94.

Pecker Berio, Talia. 'Mahler's Jewish Parable', in Mahler and his World, ed. Karen Painter. Princeton: Princeton University Press, 2002. 87-110.

Pressing, Jeff. 'Free Jazz and Avant-Garde', in The Cambridge Companion to Jazz, ed. Cooke and Horn. 202-16.

The Real Book, Vol. 1, 6th edn. Milwaukee: Hal Leonard, 2004.

Schaal, Hans-Jürgen. " "Wie können Sie das Mahler antun?” Hans-Jürgen Schaal im Gespräch mit Uri Caine'. Neue Zeitschrift für Musik 161/4 (2000), 62-4.

Schirmer, Vic, 'Meet Uri Caine'. All about Jazz <http://www.allaboutjazz.com/iviews/ucaine_1.htm> (accessed 19 November 2007).

Schuller, Gunther. 'Third Stream'; 'Third Stream Revisited', in Contemporary Composers on Contemporary Music, expanded edn., ed. Elliott Schwartz and Barney Childs with Jim Fox. New York: Da Capo, 1998. 408-12; 413-14.

Shoemaker, Bill. Review of CD, Uri Caine, Live at the Village Vanguard. Down Beat <http://www.downbeat.com/ review_detail.asp?rid $=850>$ (accessed 19 November 2007).

Wilson, Peter Niklas. 'Unerledigte Fragen: “Third Stream” zwischen Jazz und europäischer Moderne'. Neue Zeitschrift für Musik 151/6 (1990), 8-15.

-. 'Zorn, John', in The New Grove Dictionary of Music and Musicians, 2nd edn, ed. Stanley Sadie and John Tyrrell. London: Macmillan, 2001. Version at Grove Music Online, ed. Laura Macy. <http://www. grovemusic.com> (accessed 19 November 2007).

Winter, Franz. Liner notes to Gustav Mahler/Uri Caine, Urlicht/Primal Light (see Discography, Filmography). 